\title{
AKAR EPISTEMIK HEGEMONI POLITIK BARAT TERHADAP NASIONALISME DI TIMUR TENGAH
}

\author{
Mohammad Arifullah Ashaf \\ IAIN Sulthan Thaha Saifuddin Jambi \\ e-mail: simulakra.arif@gmail.com
}

\begin{abstract}
Nationalism in the Middle East until now have not been able to create an atmosphere of peace in the life of the nation. This spawned the thesis that the nationalism that developed there really is not free from the influence of Western Europe to split the power of Islamic world power. This paper is directed to probe the roots of Western European political epistemic hegemony on nationalism in the Middle East by applying the method of literature study. Hegemony of colonialism in Middle East supported the rise of nationalism. Nationalism made Islam no longer used as the basis of unity of nations in the Middle East as is in the caliphate system. Nationalism is an imported product that is inseparable to modernization with the effect of disrupting the unity of the Islamic world, especially in countries of the Middle East.

Nasionalisme di Timur Tengah hingga saat ini belum mampu menimbulkan suasana damai dalam kehidupan berbangsa dan bernegara. Hal ini melahirkan thesis bahwa Nasionalisme yang berkembang di sana sebenarnya tidak lepas dari pengaruh atau bahkan sketsa Eropa Barat untuk memecahbelah kekuatan dunia Islam. Tulisan ini diarahkan untuk menelisik akar epistemik hegemoni politik Eropa Barat atas Nasionalisme di Timur Tengah dengan menggunakan metode studi literatur. Kolonialisme yang menghegemoni Timur Tengah mendorong lahirnya Nasionalisme. Nasionalisme membuat Islam tidak digunakan lagi sebagai dasar persatuan bangsa-bangsa di Timur Tengah sebagai mana pada sistem khilafah. Nasionalisme merupakan produk impor yang tidak dapat dipisahkan dengan modernisasi, yang mengakibatkan kekacauan bagi persatuan di dunia Islam khususnya di negara-negara Timur Tengah.
\end{abstract}

Keywords: nationalism; Middle East; Western Europe; hegemony 


\section{A. Pendahuluan}

Nasionalisme sebagai produk modernitas pada akhir abad ke-18 dan awal abad ke-19 di Eropa, ${ }^{1}$ merupakan salah satu paham yang berpengaruh luas dewasa ini. Hampir semua komunitas modern diikat oleh nasionalisme dalam bentuk negara bangsa (nation-state). Kenyataan ini juga terjadi pada negeranegara di Timur Tengah, di mana kesatuan ideologi keagamaan yang sebelumnya menguasai dunia Islam telah tersingkir oleh kesatuan elemen-elemen sosial seperti bahasa, kesamaan sejarah, identitas dan solidaritas sosial ${ }^{2}$ yang berpengaruh dalam kesatuan politik suatu bangsa.

Masalahnya, nasionalisme yang diharapkan dapat memecahkan berbagai problem sosial-politik di Timur Tengah ternyata tidak membuahkan hasil yang diinginkan. ${ }^{3}$ Timur Tengah tetap merupakan kawasan dengan aktivitas politik yang panas dan rentan terhadap konflik. Sejak berakhirnya Perang Dunia II, Timur Tengah telah mengalami persengketaan politik yang pelik dan berakibat nyata terhadap konflik antar negara dan ketidakstabilan. Kerawanan regional ini menjadi lebih akut karena intervensi negara adidaya tertentu dalam urusan Timur Tengah, baik secara sosial, politik, budaya, ekonomi dan juga tentunya militer. ${ }^{4}$ Hingga kini peta wilayah Timur Tengah masih menjadi penyebab konflik, ${ }^{5}$ belum lagi persoalan Palestina dan Israel yang belum kunjung selesai hingga kini.

\footnotetext{
${ }^{1}$ Nasionalisme adalah bentuk perlawanan terhadap sistem kekuasan absolut monarki khas regim otokrasi, yang didasarkan atas kesatuan identitas dan budaya, untuk akhirnya menjadi ideologi kebangsaan bangsa-bangsa Eropa besar. Eugene Delacroix, "Nationalism", Stanford Encyclopedia of Philosophy, http://en.wikipedia.org/wiki/nationalism. Diunduh 14 Januari 2014.

${ }^{2}$ Lihat Sulfikar Amir, "Epistemologi Nasionalisme”, http://serbasejarah.wordpress.com. Diunduh 18 April, 2009.

${ }^{3}$ Pertumbuhan ideologi kebangsaan (Nasionalisme) di Timur Tengah mulai tampak ketika Nepoleon melakukan ekspedisinya ke Mesir tahun 1798. Lihat Philip K. Hitti, History of The Arabs: From the Earliest Time to the Present (NewYork: Macmillan, 1970), h. 745.

${ }^{4}$ Akibatnya, dari perspektif Sumber Daya Alam, terabaikannya politik dan batas-batas hidrologis telah mempersulit pembangunan sumber daya air. Dari sudut sosial-budaya, bangsa Kurdi, yang merupakan bangsa non-Arab, yang tersebar di Turki, Syria, Irak dan Iran, telah meminta otonomi dan seringkali mengakibatkan terjadinya benturan di antara negara-negara tersebut. Hal serupa terjadi pula pada kasus konflik berkepanjangan antara Islam Suni dan Syiah yang seringkali melewati batas-batas negara. Lihat Sulfikar Amir, "Epistemologi Nasionalisme."

${ }^{5}$ Ibid.
} 
Ada pula sinyalemen yang memperlihatkan bahwa nasionalisme yang berkembang di Timur Tengah sebenarnya tidak lepas dari sketsa Eropa Barat dan merupakan imbas dari proyek modernisme yang telah tumbuh pada masyarakat Barat modern, di mana sekularisme menjadi prinsip hidup dominan yang dicanangkan sebagai prinsip ideologis dalam menjalankan pemerintahan berdasarkan kekuatan rasional. Selain itu untuk menggantikan dasar-dasar keagamaan dan otoritas monarki, maka nasionalisme dicanangkan untuk merekat solidaritas kebangsaan dan teritorial, karena itu nasionalisme di belahan dunia Arab tidak terpisahkan dari proyek modernisme dan juga sekularisme.

Kenyataan-kenyataan tersebut di atas memperlihatkan betapa nasionalisme tidak menjadi pemecah terhadap berbagai problem yang dihadapi negaranegara di Timur Tengah, alih-alih justru memunculkan perpecahan dan konflik yang berkepanjangan. Oleh karena itu penting untuk menyoroti masalah nasionalisme di Timur Tengah dengan melacak akar epistemologinya, hingga menghasilkan sebuah pemahaman yang mendalam baik dari aspek ideologi, sosial dan politik.

\section{B. Tantangan Modernisme dan Makna Nasionalisme}

Harvey Cox menempatkan nasionalisme sebagai soko guru sekaligus anak kandung modernisme yang menjadi tantangan dunia ketiga, ${ }^{6}$ karena itu pula Fazlur Rahman melihatnya sebagai tantangan tersendiri bagi masyarakat Muslim modern, 7 yang hingga kini masih menyisakan perdebatan soal bentuk negara dalam komunitas muslim, apakah berbentuk sekuler atau agama. ${ }^{8}$

Nasionalisme yang tumbuh dari gerakan sparatis di Eropa akhir abad ke-18 dan awal abad ke-19 awalnya adalah perlawanan terhadap absolutisme monarki dan feodalisme yang kemudian berkembang menjadi ideologi kebangsaan Eropa di akhir abad ke-19. ${ }^{9}$ Barbara Ward, menyebut akar nasionalisme bermula setelah keruntuhan Kerajaan Roma Barat yang menumbuhkan kelompok

\footnotetext{
${ }^{6}$ Harvey Cox, Aspects of Political Development(Boston: Little Brown, 1965), h. 183.

${ }^{7}$ Fazlur Rahman, Islam (New York: The Chicago Press, 1979), h. 313-314.

${ }^{8}$ Altaf Gauhar, The Challenge of Islam (London: Islamic Council of Europe, 1978), h. 320.

${ }^{9}$ Eugene Delacroix, "Nationalism”, http://en.wikipwdia.org/wiki/nationalism.
} 
kesukuan, yang kemudian setelah serangkaian penaklukan membentuk negaranegara feodal. ${ }^{10}$ Sementara di Amerika nasionalisme tumbuh seiring dengan Liberalisme, terutama lewat filsafat Thomas Jefferson. Nasionalisme Amerika ini memberikan daya dorong munculnya Revolusi Perancis yang terkenal dengan gagasan, liberte, egalite, fraternite (kemerdekaan, persamaan dan persaudaraan). ${ }^{11}$ Namun demikian. pada abad ke-20 di beberapa negara, nasionalisme justru kembali ke bentuk totaliter, seperti yang dialami Jerman dan Italia. Di Italia terdapat paham fasisme yang menitikberatkan pada kedaulatan negara. Sementara dalam paham "nasionalisme-sosialis" NAZI Jerman menitikberatkan faktor ras. ${ }^{12}$ Keduanya dianggap sebagai nasionalisme ekstrim.

Melihat perkembangan di atas, benar apa yang diungkap oleh Max Weber, bahwa nasionalisme adalah kelompok korporasi yang dikoordinasikan secara imperatif, di mana pelaksanaan aturan terus dilakukan dalam wilayah yang ada dengan menerapkan kekuatan dan ancaman fisik. Unsur pokok negara adalah klaim monopoli penggunaan kekuatan fisik yang sah untuk melaksanakan aturan. Weber juga menegaskan bahwa negara adalah asosiasi hubungan manusia yang menguasai manusia lain yang di dalamnya politik digunakan sebagai upaya untuk mempengaruhi distribusi kekuasaan baik antar kelompok maupun antar negara. ${ }^{13}$

Secara konseptual nasionalisme diartikan beragam, dan yang umum diungkapkan adalah nasionalisme sebagai: 1) kulturnasi, yang berlandaskan pada formasi kesadaran dan solidaritas nasional dan state nation sebagai ideologi yang menginginkan pendirian negara; 2) loyalitas (etnis dan nasional) dan keinginan menegakkan negara; 3) identitas budaya dan bahasa, dan sebagainya. ${ }^{14}$ Secara rinci, beberapa pakar telah pula mendefiniskan nasionalisme sebagai berikut. Walter $\mathrm{S}$. Jones, memahami nasionalisme sebagai identitas

\footnotetext{
10Ita Mutiara Dewi, "Nasionalisme dan Kebangkitan dalam Teropong”, dalam Mozaik, Vol. 3, No. 3, Juli 2008, h. 4.

${ }^{11}$ Soemarsono Mestoko, Indonesia dan Hubungan antar Bangsa (Jakarta: Pustaka Sinar Harapan, 1988), h. 79.

12 Ibid., h. 82.

${ }^{13}$ Henry J. Schmandt, "A History of Political Philosophy", Ahmad Baidlowi dan Imam Baehaqi (Terj.), Filsafat Politik: Kajian Historis dari Zaman Yunani Kuno sampai Zaman Modern (Yogyakarta: Pustaka Pelajar, 2009), h. 629.

${ }^{14}$ Ita Mutiara Dewi, “Nasionalisme dan Kebangkitan dalam Teropong”, h. 2.
} 
kelompok kolektif yang secara emosional mengikat banyak orang menjadi satu bangsa. Bangsa menjadi sumber rujukan dan ketaatan tertinggi bagi setiap individu sekaligus identitas nasional. ${ }^{15}$ Sementara itu Ernest Gellner dalam nada yang serupa mengungkapkan bahwa nasionalisme merupakan prinsip politik yang memegang kuat bahwa unit politik dan nasional seharusnya kongruen. Nasionalisme dapat berbentuk sentimen maupun gerakan. Sentimen nasionalisme adalah perasaan marah yang muncul karena pelanggaran prinsip atau perasaan puas akibat pemenuhan suatu prinsip. Sedangkan gerakan nasionalis adalah sesuatu hal yang ditunjukkan oleh sentimen perasaan itu. ${ }^{16}$

Dengan demikian nasionalisme pada prinsipnya berbeda dengan patriotisme, chauvinisme dan primordialisme. Patriotisme adalah sikap seseorang yang bersedia mengorbankan segala-galanya untuk kejayaan dan kemakmuran tanah airnya atau semangat cinta tanah air. Chauvinisme adalah paham cinta tanah air secara berlebih-lebihan. Meskipun demikian, antara nasionalisme, patriotisme dan chauvinisme sama-sama berkaitan dengan paham cinta tanah air atau bangsa/negaranya dalam konteks lembaga negara bangsa (nationstate)..$^{17}$

\section{Kolonialisme, Pembaruan dan Nasionalisme di Timur Tengah}

Setelah jalan laut ditemukan Cristoper Colombus (1492 M) yang menemukan benua Amerika dan Vasco da Gama yang menemukan jalan ke Timur melalui Tanjung Harapan (1498 M), berturut-turut benua Amerika dan kepulauan Hindia segera jatuh ke bawah kekuasaan Eropa. Dengan demikian Eropa tidak lagi tergantung kepada jalur lama yang dikuasai oleh umat Islam, sehingga perdagangan Eropa meningkat pesat, yang kondisi ini menjadi salah satu pendorong kemajuan Eropa dalam sejarah dunia. ${ }^{18}$ Kemajuan Eropa yang pesat menjadikannya penguasa di negeri-negeri Islam di Asia Tenggara, Anak

\footnotetext{
${ }_{15}$ Walter S. Jones, Logika Hubungan Internasional 2: Kekuasaan, Ekonomi Politik Internasional dan Tatanan Dunia (Jakarta: Gramedia Pustaka Utama, 1993), h. 182.

${ }^{16}$ Richard K. Betts (ed.), Conflict After the Cold War: Arguments on Causes of War and Peace, (New York: MacMillan, 1994), h. 280.

${ }^{17}$ Ita Mutiara Dewi, “Nasionalisme dan Kebangkitan dalam Teropong”, h. 2. 26.

${ }^{18}$ Lothrop Stoddard, Dunia Baru Islam (The New World of Islam) (Jakarta: Panitia Penerbit, 1966), h.
} 
Benua India, dan Timur Tengah..$^{19} \mathrm{Hal}$ inilah yang mendorong lahirnya babak baru dalam sejarah dunia Islam, yaitu babak penjajahan Barat terhadap dunia Islam, yaitu masa setelah melemahnya kekuatan Turki Utsmani dan masa pencerahan Eropa. ${ }^{20}$

Memasuki masa kolonialisme yang suram, dunia Muslim di Timur Tengah mulai menyuarakan kebangkitan dan nasionalisme. Kebangkitan di Timur Tengah didasari oleh beberapa hal seperti pemurnian ajaran Islam dan penerimaan gagasan-gagasan dan ilmu pengetahuan dari Barat. Jamaludin alAfghani (1839-1897) di Mesir, adalah tokoh pertama yang menyadari sepenuhnya dominasi barat dan bahayanya jika tidak segera dipecahkan. Melalui panIslamisme ia ingin memperkuat barisan Muslim untuk menghadapi kolonialisme Barat.21 Ia telah mengubah Islam dari kepercayaan agama menjadi ideologi politik-agama, dengan menekankan sasaran yang secara tradisional kadang dianggap tidak religius. Islam baginya adalah sumber solidaritas. Ide inilah yang kemudian menjadi penggerak lahirnya gerakan Islam dan nasionalisme di berbagai penjuru dunia Islam.22

Nasionalisme sendiri dalam konsepsi Islam diistilah sebagai al-wațaniyah, merepresentasikan kesatuan berdasarkan teritorial atau geografis yang disertai sentimen așhabiyyah. Paham ini kemudian menyebar ke dunia Islam yang sedang berpacu untuk melepaskan diri dari penjajahan. ${ }^{23}$ Dengan demikian, penjajahan di Timur Tengah telah mendorong lahirnya nasionalisme di Timur Tengah, seperti nasionalisme Mesir, Nasionalisme Arab, dan juga nasionalisme Suriah, Lebanon, Palestina, Hejaz, Iraq, Kuwait, Bahrain, hingga ke Afrika Utara. Semangat nasionalisme ini juga diperkuat oleh respon terhadap usaha Barat untuk mendirikan negara Yahudi di Palestina. Maka munculah beberapa pergerakan dan perlawan melawan imperialisme Barat, seperti yang terjadi di Maroko, Aljazair,

\footnotetext{
${ }^{19} \mathrm{Ibid}$, h. 26.

${ }^{20}$ Sejarah renaisans Eropa dapat dibaca dalam Alison Brown, "The Renaissance”, terj. Saut Pasaribu, Sejarah Renaisans Eropa (Yogyakarta: Kreasi Wacana, 2009).

${ }^{21}$ Ali Rahnema (ed.), Para Perintis Zaman Baru Islam (Bandung: Mizan, 1995), h. 17.

22Ibid., h. 29. Bagi Fazlur Rahman gerakan di atas bersifat responsif yang telah mempengaruhi perjuangan lokal atau nasional di berbagai penjuru wilayah Islam, terutama Turki dan India, baik dalam bentuk pan-Islamisme ataupun Nasionalisme. Fazlur Rahman, Islam, h. 333.

${ }^{23}$ Noor Zaman, et. al., "Islam and Nationalism: A Contemporary View", dalam Interdisciplinary Journal of Contemporary Research in Business, Vol. 4, No. 5, September 2012: 393- 400, h. 396.
} 
Mesir, dan Tunisia. Sementara pada abad ke-20 negara-negara jajahan Inggris seperti Iraq dan negara-negara teluk diberikan kemerdekaan. ${ }^{24}$

Menurut sebagian pakar, nasionalisme di dunia Islam tidak datang dengan sendirinya, melainkan masuk melalui sekolah-sekolah asing yang didirikan di wilayah Islam, dari para pelajar Islam yang belajar di dunia Barat, serta dari para misionaris maupun agen-agen asing yang menyusup ke dunia Islam. Hal ini terbukti dengan adanya American University of Beirut, Libanon. Saat para misionaris mendapatkan kesempatan untuk mendirikan pusat kegiatan di wilayah Islam, mereka mulai mencari kesempatan untuk melakukan agitasi terhadap warga negara Daulah Islam, sehingga pada tahun 1841 keributan serius terjadi di pegunungan Libanon antara orang-orang Kristen dan orangorang Druze. Khalifah Utsmani yang berada di bawah tekanan dan pengaruh negara asing kemudian dibujuk agar mau membentuk pemerintahan baru di Libanon yang terpisah dari Turki. Wilayah itu kemudian dibagi ke dalam dua propinsi yang terpisah di mana satu bagian untuk orang-orang Kristen dan bagian yang lain untuk orang-orang Druze. Khalifah Utsmani menunjuk seorang wali (gubernur) bagi kedua wilayah tersebut untuk menyelesaikan perselisihan antara kedua kubu. Tetapi Inggris dan Perancis berusaha melibatkan diri ketika Khalifah Utsmani hendak menyelesaikan huru-hara, meskipun kedua negara tersebut merupakan pembuat keributan yang sebenarnya dengan melalui para agennya yaitu Niven Moore, Konsul Inggris di Beirut dan saudaranya, Richard Wood. ${ }^{25}$

Selama pertengahan abad ke-19, kaum misionaris tidak hanya memfokuskan kegiatan pada sekolah-sekolah, pusat penerbitan dan klinik pengobatan, tetapi bergerak lebih jauh memantapkan asosiasi mereka. Pada tahun 1842, sebuah komite dibentuk untuk memantapkan asosiasi keilmuan di bawah perlindungan misi Amerika. Komite ini bekerja selama lima tahun sampai terbentuknya asosiasi yang disebut sebagai Association of Arts and Science. Anggotanya termasuk Nasif al-Yaziji dan Boutros al-Bustani. ${ }^{26}$ Pada tahun 1875

\footnotetext{
${ }^{24}$ Gunawan, "Sistem Pemerintahan Masa Imperialisme Barat dan Pergerakan Nasional di Timur Tengah", dalam laman http://gunawanktt.blog.uns.ac.id/2014/10/07/evolusi-sistem-pemerintahandi-timur-tengah- bag-3/. diunduh 3 Januari 2016.

25Shabir Ahmed, Akar Nasionalisme di Dunia Islam (Bangil: Tim Al-Izzah, 2002), h. 39.

26Ibid., h. 43.
} 
juga dibentuk Secret Association di Beirut yang bertujuan menggulirkan konsep Nasionalisme Arab, khususnya di Syria dan Libanon. Pendirinya adalah lima pemuda yang dididik di Protestan College Beirut. Selain menghembuskan ide Nasionalisme Arab, mereka dalam bukunya juga menuduh bahwa Turki telah merebut Dawlah Khiläfah Islämiyyah dari tangan orang Arab dan melanggar syari'at serta mengabaikan al-dīn. Hal ini menunjukkan keaslian asosiasi dan tujuan pendiriannya yaitu untuk mengorbankan semangat menentang Dawlah Khiläfah Islämiyyah untuk menanamkan kecurigaan dan sikap skeptis sampai akhir keruntuhannya.

Di Turki sendiri setelah terjadi perdebatan panjang antara kaum nasionalissekuler dengan Islamis, telah menyebabkan Turki mengganti haluannya sebagai negara nasionalis. Pada tahun 1924, Mustafa Kamal Attaturk membubarkan Dawlah Khilāfah Islāmiyyah yang berpusat di Turki Utsmani yang telah berhasil menjadi negara Islam terbesar lebih kurang selama enam abad. Attaturk mengganti Khilafah dengan sistem nasionalis-sekuler ala Barat. Dunia Islam pun berkeping-keping dan semakin didominasi oleh kolonial Barat khususnya Inggris, Perancis, Amerika Serikat dan Rusia. Sejak keruntuhan Turki Utsmani ini, telah muncul banyak negeri muslim yang menggunakan ikatan Nasionalisme seperti Mesir, Turki, Saudi Arabia, negara-negara Teluk, Iran, Pakistan, negara-negara Balkan, dan lain-lain. Negeri-negeri muslim yang awalnya berada dalam satu negara terpecah menjadi lebih dari 50 nation-state dengan konflik internal dan eksternal yang bahkan belum terselesaikan sampai sekarang. ${ }^{27}$

\section{Nasionalisme dan Kehidupan Sosial-Politik Timur Tengah}

Abdelaziz A. Ayyad mengungkapkan bahwa kehidupan sosial-politik di Timur Tengah abad ke-20 dipengaruhi oleh peralihan bangsa Arab menjadi nation-state (nasionalisme). Proses ini sendiri dilihat oleh Ayyad sebagai proses yang mekanis. ${ }^{28}$ Secara sosial nasionalisme telah mempengaruhi identitas sosial masyarakat Timur Tengah. Persoalan identitas inilah yang kerap menjadi masalah sosial seiring dengan terbentuknya nasionalisme di Timur Tengah

\footnotetext{
${ }^{27}$ Adhyaksa Dault, Islam dan Nasionalisme: Reposisi Wacana Universal dalam Konteks Nasional (Jakarta: Pustaka Al-Kautsar, 2005), h. 176.

${ }^{28}$ Abdelaziz A. Ayyad, Arab Nationalism and the Palestinians 1850-1939 Jerusalem: Passia, Palestinian Academic Society for the Study of International Affair, 1999), h. 4.
} 
yang tekondisi dalam iklim modern. Beberapa kalangan menilai nasionalisme telah menggerogoti identitas murni masyarakat Arab di Timur Tengah dalam bentuk krisis identitas yang terjadi di berbagai wilayah negara Islam di Timur Tengah.

Wilayah Timur Tengah, yang terbentang dari beberapa negara di Afrika Utara dan Asia Barat, kadang dianggap sebagai dunia yang homogen secara budaya maupun tampilan fisik, sebagaimana yang diasumsikan oleh Hudson yang menyatakan bahwa budaya merupakan identitas yang ditentukan oleh aspek persamaan etnisitas dari persamaan bahasa, warna kulit, dan kesamaan sejarah. ${ }^{29}$ Namun temuan ini tidak sepenuhnya benar, karena jika diperhatikan dunia Arab juga memiliki heterogenitas, paling tidak dalam 4 kategori yaitu: linguistically diverse but religiously cohesive; religiously diverse but linguistically cohesive; both linguistically and religiously diverse dan divided between natives and nonnatives. Heterogenitas ini bahkan semakin kentara dewasa ini, disebabkan oleh globalisasi yang semakin menguat, ${ }^{30}$ yaitu ketika negara-negara di Timur Tengah terpecah menjadi negara-negara tersendiri dengan identitasnya sendiri. Kondisi ini menjadikan konflik dan perpecahan sebagai isu global yang mengemuka di Timur Tengah, bahkan hingga dewasa ini.

Kondisi ini didorong pula oleh beberapa hal: pertama adalah mengenai persoalan batas-batas dan legitimasi entitas berdaulat yang ada, yang kedua adalah adanya ketidaksamarataan (inequalities) dalam kehidupan bermasyarakat yang dipenuhi dengan kepribadian Nasionalisme akan etnoreligius yang kuat, dan yang terakhir adalah permasalahan-permasalahan yang muncul dari integrasi kaum minoritas dalam sebuah negara. ${ }^{31}$ Artinya bahwa identitas nasional atau national identity negara-negara Timur Tengah pada dasarnya belum terbentuk sepenuhnya, masih terdapat gap antar suku, sekte dan juga perbedaan simbol-simbol keagamaan. Hal ini digambarkan Hudson sebagai tribes, particular sect, dan Islamic Symbols.32 Ketiga hal ini memang bukan

${ }^{29}$ A. Drysdale \& G.H. Blake, "National Integrations: Problems, Processes and Prospects", dalam The Middle East and North Africa: A Political Geography, New York: Oxford University Press, 1985: 149-190, h. 150 .

30Ibid,.h. 156.

${ }^{31}$ Michael C. Hudson, "Cultural Pluralism in the Arab World", dalam Arab Politics: The Search for Legitimacy, New Haven and London: Yale Univesity Press, 1977:56-81, h. 56.

${ }^{32}$ Ibid, h. 34 . 
pondasi utama bagunan negara, namun hingga saat ini ketiganya merupakan kunci penting untuk memahami wilayah Timur Tengah. Sebagaimana telah diungkap, bahwa negara-negara Timur Tengah memiliki banyak persamaan dibandingkan perbedaan. Di seluruh dunia, kawasan yang memiliki homogenitas penduduk terbesar adalah kawasan Timur Tengah. ${ }^{33}$ Hal ini diakibatkan oleh dominasi Islam di Timur Tengah. Walaupun demikian tetap terdapat beberapa perpecahan yang diakibatkan oleh minoritas Kristen atau nonMuslim ataupun non-Arab yang mencoba melakukan pemberontakan seperti yang dilakukan oleh kaum Kurdi di Iraq atau penduduk kulit hitam di wilayah Sudan Selatan.

Kebudayaan Timur Tengah umumnya sangat kental kaitannya dengan agama, terutama Islam. Dalam perkembangannya kemudian masyarakat Timur Tengah dalam entitas budaya dan agamanya terbagi dalam empat kategori besar, yaitu: Muslim Sunni orthodox, termasuk di dalamnya kalangan Shi'ah; bangsa Arab yang non-Muslim (terutama Kristen dan Yahudi); non-Arab yang Muslim seperti Kurdish di Iraq dan Berber di Algeria; dan non-Arab yang nonMuslim (Animis dan Kristen-Afrika). ${ }^{34}$ Namun demikian bangsa Arab tetap merupakan mayoritas, yang dalam perkembangannya pluralitas ini telah memancing konflik di dunia Arab.

Di sisi lain, secara politis pemikiran politik yang menyeruak ke dunia Islam pada abad ke-20 telah membawa perubahan yang signifikan pada sistem pemerintahan di Timur Tengah. Nasionalisme khususnya telah menjadi icon modern yang tidak terpisahkan dari dunia global dewasa ini. Budi Mulyana mengungkapkan terdapat beberapa isu politik internasional di Timur Tengah yang masih belum terselesaikan hingga dewasa ini, mulai dari Zionisme, Nasionalisme Arab, dan ideologi kiri yang kini melahirkan gerakan Terorisme/ fundamentalisme. ${ }^{35}$ Masalah Zionisme yang berujung pada konflik Arab-Israel serta gerakan Fundamentalisme dan Terorisme akan diulas lebih jauh.

33I Ibid,.h. 38.

${ }^{34}$ Ibid., h. 58.

${ }^{35}$ Budi Mulyana, "Pemikiran Politik di Timur Tengah", dalam https://hbmulyana.wordpress.com /2008/01/05/pemikiran-politik-di-timur-tengah, diunduh 5 Januari, 2008. 


\section{Konflik Arab-Israel}

Konflik Arab-Israel sebenarnya telah sejak abad ke-19, saat imigrasi Yahudi yang semakin massif ke Palestina sebelum tahun 1981, hingga mendatangkan penentangan sporadis dari masyarakat Palestina. Akibatnya pada tahun itu diadakan kongres Zionis pertama. Saat itu masyarakat Palestina meminta otoritas Turki Utsmani untuk menerbitkan aturan pelarangan imigrasi bangsa Yahudi ke Palestina, walaupun kemudian aturan diterbitkan namun tidak mendapatkan hasil yang diharapkan, mengingat adanya hubungan politik antara Turki dan Yahudi. Di samping itu otoritas Turki Utsmani, khususnya Amin Arsalan Qa'im Qam, justru melihat pentingnya untuk melokalisir bangsa Yahudi dalam satu wilayah yaitu Palestina, karena itu ia giat mengusahakan transformasi Palestina dari tangan bangsa Arab ke bangsa Yahudi. Mengingat jika krisis kebangsaan Yahudi dibiarkan tidak hanya akan membahayakan Palestina namun juga kekhalifahan Turki Utsmani. ${ }^{36}$

Pada masa modern konflik terus berlangsung dan justru menguat saat otoritas Persatuan Bangsa-Bangsa (PBB) mengakomodir keinginan Israel untuk mendirikan negara berdaulat dengan membagi Palestina dalam dua negara yaitu Yahudi/ Israel dan Arab/ Palestina. Ketetapan ini ditentang oleh negara-negara Arab pada tahun 1948. Mereka memutuskan perang untuk membela saudaranya Palestina. Sayangnya persatuan bangsa Arab tidak berdaya menghadapi Israel hingga perang berakhir dengan kemenangan Israel bahkan terjadi perluasan wilayah dari yang sebelumnya ditetapkan oleh PBB. ${ }^{37}$ Ini menandakan betapa lemah kekuatan bangsa Arab yang telah terpilah dalam bangsa-bangsa idenpenden, hingga secara politik-ekonomi mereka terpecah belah. Kenyataan inilah yang bertahan hingga kini.

Menurut Li Yi, peneliti post-doktoral ilmu politik Universitas Fudan, konflik Arab-Israel yang terjadi pada abad ke-20 sebenarnya diakibatkan oleh akar sejarah nasionalisme di Timur Tengah dan sedikit sekali hubungannya dengan ketegangan ego kebangsaan masing-masing sebagai bangsa yang paling berhak

\footnotetext{
${ }^{36}$ Abdelaziz A. Ayyad, Arab Nationalism and the Palestinians 1850-1939 Jerusalem: PASSIA Publication, 1999), h. 37-38. 184.

37Martin Kramer, "Arab Nationalism: Mistake Identity", dalam Daedalus, Summer 1993: 171-206, h.
} 
terhadap tanah Palestina, karena itu konflik dan perang terus berkelanjutan hingga kini. Perang enam hari Arab-Israel pada tahun 1967 juga merupakan akibat dari situasi Timur Tengah yang menghadapkan dua sistem Nasionalisme antara Nasionalisme sekular Arab dan "Nasionalisme" Fundamentalisme Islam, terutama Nasionalism Pan-Arabisme. ${ }^{38}$

Jamal Abd. Nasser (Gamal Nasser) awalnya telah menempatkan ide Nasionalisme Arab, termasuk Palestina dalam bingkai liberal modern yang mengutamakan persatuan bangsa Arab dan Sosialisme. Namun perang yang terjadi di Timur Tengah antar bangsa Arab sendiri dan juga Israel telah mematahkan anggapan di atas, selain itu, setelah Nasser wafat, persatuan bangsa Arab tidak pernah lagi terwujud. Dalam situasi inilah Li Yi menyatakan bahwa Fudamentalisme Islam telah mengambil keuntungan untuk menjelaskan kegagalan bangsa Arab karena meninggalkan ajaran Islam sejati. Hasilnya, Fundamentalisme Islam mulai melebarkan pengaruhnya di kelas bawah. Ikhwān al-Muslimīn yang sebelumnya ditekan oleh pemerintahan Nasser di Mesir mulai bangkit dan mendapatkan dukungan dari beberapa ormas Islam radikal seperti Hamas dan Hizbullah, sehingga sejak tahun 1980-an nuansa keagamaan telah mewarnai konflik berkepanjangan antara Arab-Israel, di mana Hamas dan Hizbullah menjadi pemain utama di luar pemerintah. ${ }^{39}$

Pemerintah Palestina selanjutnya telah jatuh pada posisi yang sulit serta kehilangan legitimasinya di mata rakyat. Sehingga banyak pakar seperti J. Rourke menyatakan Palestina sebagai bangsa tanpa negara. ${ }^{40}$ Situasi ini dipersulit oleh kenyataan bahwa negara Palestina terbentuk dalam proses agresi kolonialisme Barat (Inggris) dan Zionisme, serta pencaraian kesetaraan politik dan juga kemerdekaan di bawah bayang-bayang Turki Utsmani yang memiliki kepentingan berbeda terhadap Palestina. ${ }^{41}$ Karena itu kemudian

\footnotetext{
${ }^{38} \mathrm{Li}$ Yi, "Edward Said's Thoughts and Palestinian Nationalism”, dalam Journal of Middle Eastern and Islamic Studies (in Asia), Vol. 5, No. 3, 2010: 105-120, h. 107.

${ }^{39} \mathrm{Li} \mathrm{Yi}$, ibid, h. 108.

40J. Rourke, International Politics in the World Stage (Beijing: Peking University Press, 2005), h. 197.

${ }^{41} \mathrm{H}$. Yang dan X. Ma, "The Orogin and Early Exprerience of the Pakistan Nationalism", dalam West Asia and Afrika, No. 2, 2002, h. 44. Zionisme terutama merupakan "lawan" abadi yang dihadapi oleh bangsa Arab di Timur Tengah. Nadeem Rouhana, seorang Professor pada Tel Aviv University yaang berkebangsaan Palestina-Arab misalnya mengungkapkan bahwa Zionisme merupakan musuh bersama bangsa Arab yang ingin mewujudkan kemerdekaan Palestina, hingga memiliki identitas kebangsaannya sendiri. Nadeem Rouhana, Palestinian Citizen in an Ethnic Jewish State (New Haven: Yale University Press, 1997), h. 67.
} 
terjadi perang enam hari Arab-Israel tahun 1967, yang telah membangkitkan Nasionalisme Palestina menuju era baru, saat Palestina dinyatakan resmi medeka tahun 1968. Sejak saat itu bangsa Palestina terus mengembangkan diri hingga berdirinya organisasi nasional, Fatah di bawah pimpinan Yasser Arafat. Kemudian PLO juga dipimpin oleh Yasser Arafat, yang berhasil mewujudkan aspirasi masyarakat Palestina sebagai bangsa yang berdaulat. ${ }^{42}$

Walaupun demikian kenyataan hari ini menunjukkan bahwa kedaulatan negara Palestina terus mendapatkan rongrongan dari Israel yang terus berupaya menggerogoti wilayah Palestina, hingga menyebabkan konflik berkepanjangan antara Palestina-Israel. Masalah ini tampaknya akan terus berlanjut bila kesepahaman tidak terjalin antar dua entitas bangsa, negara dan budaya.

\section{Gerakan Fundamentalisme dan Terorisme}

Gerakan fudamentalisme dan terorisme di Timur Tengah biasanya diidentikkan dengan Islam, karena itu beberapa tahun lalu terkenal slogan "Islam is Terorism". Kenyataan di lapangan tidaklah demikian, karena gerakan Fundamentalisme dan juga Terorisme juga dilakukan oleh umat non-Islam. Louis Snyder mencatat bahwa hubungan antara Israel dan negara-negara Arab cukup unik, karena disokong oleh ide politik Zionisme dan sarat dengan muatan keagamaan, yaitu Judaisme. Hal ini menjadikan konflik Arab-Islam dan IsraelYahudi sarat dengan muatan politik kebangsaan dan semangat keagamaan yang kental. ${ }^{43}$ Kondisi demikian ini telah menjadi pemicu lahirnya gerakan fundamentalisme dan terorisme di Israel. Gerakan ini bahkan cukup subur dan diarahkan untuk meneror bangsa Palestina, Mark Juergensmeyer misalnya mencatat bahwa: "In talking with Israel's religious activists, it became clear to me that what they were defending was not only the political entity of the state...but a vision of a Jewish society that had ancient roots". ${ }^{4}$

\footnotetext{
${ }^{42}$ K. Zhao, "From Arab Nationalism to Plastinian Nationalism: The Growth Process of the Palestinian Nation", dalam World Ethno-National Stidies, No.12007, h. 22.

${ }^{43}$ Lihat Jason Andrukaitis, "Egyptian and Israeli Nationalism: A View into the Relationship Between Nationalism and Violance", Junior Honors Seminar: Beyond Religious Fundamentalism, Rivier College, 2006, h. 5.

${ }^{44}$ Mark Juergensmeyer, Terror in the Mind of God: The Global Rise of Religious Violence (Los Angeles: University of California, 2003), 46.
} 
Term Israel dengan demikian, tidak hanya merujuk pada sebuah nationstate, namun juga agama (Yahudi) yang memiliki musuh yang jelas yaitu ArabPalestina-Islam. Hal serupa sebenarnya juga terjadi di dunia Arab. Jika terorisme Israel berjuang merebut tanah leluhurnya yang telah ditinggalkan sejak tahun 1211 SM., maka terorisme Arab didorong oleh semangat jihad dengan cita-cita menegakkan kembali khilafah Islam di dunia Islam. ${ }^{45}$ Artinya masingmasing memiliki alibi historis yang kuat didasarkan atas tradisi agama. Walaupun agama tidak memainkan aturan vital dalam budaya, namun umat Yahudi melihat Palestina sebagai tanah yang telah dijanjikan Tuhan bagi mereka. Itulah mengapa Israel berusaha mempertahankan Palestina berapapun harga yang harus mereka tanggung. ${ }^{46}$

Sementara itu, gerakan Fundamentalisme dan Terorisme yang dilakukan "segelintir" umat Islam dirujuk oleh beberapa pakar dari gerakan Wahabisme yang diklasifikasikan sebagai scriptural fundamentalism. Menekankan pentingnya kembali pada sumber murni Islam yang sejati, yaitu Qur'an dan Sunnah, yang dapat ditelisik dari pemikiran Ibn Taimiyyah, tokoh gerakan salafiyah, dan pemikiran Ahmad ibn Hanbal, pendiri mazhab Hambali yang mengajarkan keutamaan sunnah daripada qiyas. Pada masa awal Islam, ide-ide Fundamentalisme sebenarnya juga telah ada, disemai oleh kelompok Khawarij, yang menolak segala bentuk hukuman di luar hukum Tuhan, Lā hukma illa Allāh (tidak ada hukum kecuali hukum Allah). ${ }^{47}$ Karena itu beberapa ahli terkadang melihat gerakan Fundamentalisme Islam dewasa ini sebagai refresentasi dari newHawarizm.

Gerakan Wahabi muncul pada abad ke-19 oleh seorang ulama-pembaruan asal Mesir Muhammad Abduh, orang pertama yang mengajarkan bahwa Islam compatible dengan modernitas. Namun semangat Abduh untuk kembali ke

\footnotetext{
45Jason Andrukaitis, "Egyptian and Israeli Nationalism”, 5.

${ }^{46}$ Satu hal yang menarik dari aksi terorisme Israel adalah mereka tidak mengatasnamakan pemerintah namun agama. Jika kebijakan pemerintah bertentangan dengan apa yang diyakini maka mereka juga akan menyerang pemerintah. Kasus terbunuhnya PM. Israel Yitzhak Rabin misalnya dilihat oleh beberapa kalangan disebabkan oleh kepentingan agama. Hal ini pula yang menyebabkan kaum fundamentalis Yahudi dapat mengumpulkan pengikut dalam jumlah besar di Israel dari pada di negara-negara sekuler. Mark Juergensmeyer, Terror in the Mind of God, 46-47.

${ }^{47}$ Budi Mulyana, "Pemikiran Politik di Timur Tengah”, https://hbmulyana.wordpress.com/2008/ 01/05/pemikiran-politik-di-timur-tengah. Diunduh 5 Januari, 2008.
} 
ajaran dasar Islam dan menghapus kolonialisme dari dunia Islam telah dipahami secara sempit oleh kaum Fundamentalis Islam. Dengan ghïrah Islāmiyyah-nya, mereka berkeinginan untuk menegakkan syari'at Islam dan pendirian negara Islam sebagai agenda utama. Alih-alih mereka berupaya untuk menegakkan kembali sistem kekhilafahan dalam dunia Islam, karena Islam tidak mengenal batasan-batasan berdasarkan etnis dan geografis. Nasionalisme bagi mereka dianggap sebagai așhābiyyah dan bertentangan dengan Islam, karena didasarkan hanya pada persamaan kebangsaan. Satusatunya ikatan yang menghimpun seluruh masyarakat Islam adalah kesamaan aqidah, yang terangkum dalam bentuk masyarakat ideal yang disebut ummah. Kelompok Ikhwanul Muslimin di Mesir dan Hizbut Tahrir di Palestina adalah kelompok yang ingin menegakkan kembali sistem kekhilafahan. Sementara itu kelompok-kelompok lainnya memiliki orientasi politik yang bersifat lokal. ${ }^{48}$

Ketika gerakan fundamentalisme ini bersentuhan dengan modernitas dan politik internasional yang mendiskriditkan dunia Islam, maka terorisme menjadi subur sebagai gerakan pembelaan Islam (jihād). Dalam konteks ini terorisme muncul oleh pemahaman Islam yang sempit dan juga politik internasional.

Persoalan fundamentalisme di Timur Tengah ini hanya sekelumit persoalan yang turut memperkeruh hubungan Israel-Palestina yang hingga kini masih terus mengalami jalan buntu. Harapan ke depan adalah tumbuh sikap keterbukaan masing-masing pihak untuk dapat menciptakan kedamaian dengan beranjak pada pemahaman bahwa Palestina dalam kenyataannya memang menjadi tanah suci tiga agama. ${ }^{49}$ Artinya semangat berbagi tampaknya harus ditonjolkan untuk memupus kekerasan, demi tercapainya perdamaian.

Melihat kenyataan di atas, dapat dikatakan bahwa nasionalisme yang berdasarkan atas persamaan bangsa dan ataupun bahasa telah berdampak pada peminggiran terhadap Islam sebagai pemersatu. Demikian juga telah berdampak pada berbagai masalah di Timur Tengah yang terus bergejolak. Dalam proses inilah sketsa Barat atas dunia Islam di Timur Tengah terbukti.

\footnotetext{
${ }^{48}$ Ibid.

${ }^{49}$ Lihat: Rodney Stark, One True God: Historical Consequences of Monotheism (Princeton: Princeton University Press, 2001).
} 


\section{E. Nasionalisme dan Posisi Islam di Timur Tengah}

Nasionalisme berdasarkan penjabaran di atas, sebenarnya berimbas besar terhadap tersingkirnya sistem politik Islam, yang pada akhirnya akan menyingkirkan nilai-nilai Islam. Persoalannya adalah apakah hal ini merupakan realitas atau mitos jika dihadapkan pada kenyataan faktual politik Timur Tengah? Untuk menjawab pertanyaan ini, maka penelisikan terhadap sejarah nasionalisme di Timur Tengah dan pergumulannya dengan tradisi khilafah Islam menjadi penting untuk diketengahkan.

Sejarah perkembangan nasionalisme di Timur Tengah tidak dapat dilepaskan dari usaha para pembaharu Islam seperti Muhammad Abduh ataupun Jamaluddin Afghani, yang telah merangsang bangsa-bangsa Muslim untuk memberontak terhadap dominasi Eropa, dengan konsep pan-Islamisme. Namun setelah runtuhnya benteng khilafah Islam terakhir di Turki pasca Perang Dunia I, negara bangsa Muslim modern mulai melakukan perlawanan terhadap kolonialisme Eropa dan mengambil bentuk solidaritasnya sendiri dalam nasionalisme untuk menggantikan gerakan solidaritas Pan-Islamisme yang didasarkan pada persatuan keagamaan. Gerakan nasional ini mulai menekankan faktor-faktor nasional, sejarah dan kebahasaan yang berbeda dengan kesatuan keagamaan. ${ }^{50}$

Nasionalisme merupakan konsep baru di Timur Tengah yang diadopsi dari bangsa kolonial Barat, sehingga Nasionalisme memiliki perbedaan signifikan dengan konsep Pan-Islam yang telah dipromosikan oleh para pembaru Islam sebelaumnya. Persatuan Islam menginginkan adanya solidaritas dunia Islam dalam menghadapi dan sekaligus menggalang kekuatan untuk mengusir kolonialisme Barat, sementara nasionalisme mendasarkan pandangannya pada unsur-unsur formatif di luar agama, sehingga ia menjadi konsep yang baru di dunia Islam dan Timur Tengah khususnya. Karena itulah Ali Mohammed Naqvi menyebut Nasionalisme merupakan produk impor yang dengan sengaja diekspor oleh para bangsa kolonial untuk mengacaukan persatuan di dunia Islam. 51

\footnotetext{
${ }^{50}$ Kemal H. Karpat (ed.), Political and Social Thought in the Contemporary Middle East (New York: Praeger Publisher, 1982), h. xxiv.

${ }^{51}$ Ali Mohammed Naqvi, "Islam and Nationalism", dalam laman http://www.al-islam.org/ islamandnationalism/9.html., diunduh 15 Februari, 2008.
} 
Namun demikian, munculnya semangat nasionalisme yang didasarkan nation-state tidak eksis dengan otomatis terdapat pergumulan yang cukup ketat dengan Pan-Islamisme yang tetap mendasarkan kesatuannya pada persamaan keyakinan agama. Figur al-Afghani, Abduh dan murid-muridnya adalah tokoh yang getol menyuarakan pan-Islamisme dan kematian mengusir penjajah dari tanah Islam. Akan tetapi pada saat selanjutnya muncul pula tokoh-tokoh yang menyuarakan nasionalisme, khusunya nasionalisme Arab yang mendasarkan diri pada persatuan kebangsaan seperti yang diusung oleh Lutfi al-Sayyid (1872-1963).52 Tidak seperti mentornya al-Afghani dan Abduh, agama dalam pemikiran politik Lutfi tidak berperan besar, Islam baginya semata panutan bagi pemeluknya saja. Sebaliknya ia mengembangkan pemikiran politiknya berdasarkan ide-ide kebebasan Barat. Karena itu menurutnya pemerintah sewajarnya memikili dan menjadi satu kekuatan dengan kontrol yang kuat untuk mempertahankan keamanan dan keadilan serta mempertahankan rakyat dari serangan musuh..$^{53}$ Lutfi juga menganjurkan agar orang-orang Mesir mempelajari sejarah Pharao dan Arab lama, untuk membantu mendefinisikan siapa sebenarnya diri mereka. Karena baginya ide umat Islam tidak relevan lagi dengan masa sekarang dan bahwa solidaritas Islam merupakan ide yang dimunculkan oleh kolonialis Eropa, untuk melumpuhkan perjuangan nasional orang-orang Mesir. ${ }^{54}$

Nasionalis Mesir yang lain adalah Sa'd Zaghlul (1857-1927).55 Pada tahun 1923, saat Partai Wafd memenangkan pemilihan parlemen, ia diangkat sebagai Perdana Menteri, yang kemudian dipaksa berhenti karena adanya kerusuhan

\footnotetext{
${ }^{52}$ Pendidikan awalnya di sebuah sekolah al-Qur'an, dilanjutkan ke sekolah dasar modern di Mesir dan seterusnya masuk ke Fakultas Hukum. Selama berada di Fakultas Hukum, ia bertemu dengan Muhammad Abduh dan menjadi muridnya. Setelah lulus, selama beberapa tahun ia menjadi pegawai pemerintah, ketika itulah ia mengenal pemikiran-pemikiran Eropa. Setelah menjadi pegawai pemerintah, ia membentuk People's Party (Partai Rakyat) dan menjadi editor majalah Al-Jaridah, yang telah banyak mempengaruhi kaum terpelajar Mesir. Ketika penerbitan al-Jaridah dihentikan pada tahun 1915, Lutfi bekerja sebagai profesor filsafat di Universitas Mesir (sekarang Universitas Kairo) dan kemudian menjadi rektor. Ibraheem Yaqoub El-Zakzaky, "Nationalisme", dalam http://www. islamicmovementorg/nationalism.html\#introduction, diunduh 15 Februari 2008.

${ }^{53}$ Albert Hourani, Arabic Thought in Liberal Age: 1798-1939 (Cambridge: Cambridge University Press, 1983), h. 174.

${ }^{54}$ Ibid., h. 178.

55Ia mendapat pendidikan di Universitas Al-Azhar, kemudian bertemu dengan Afghani dan menjadi muridnya. Albert Hourani, Arabic Thought in Liberal Age, h. 214
} 
internal di Mesir dengan Inggris. Pemikiran politiknya bergerak jauh dari misi pembaharuan yang dilakukan Abduh, dan menganjurkan kemerdekaan politik dan persatuan Mesir yang didasarkan pada sentimen nasional dari pada didasarkan pada garis keagamaan. ${ }^{56}$

Hal ini pula yang dilakukan oleh Ali Abd al-Raziq (1888-1966), yang menyerang lembaga kekhalifahan dan dasar-dasar otoritas politik Islam. Menurutnya, al-Qur'an tidak pernah mengindikasikan secara implisit lembaga kekhalifahan dan bahwa Nabi tidak pernah bermaksud membangun pemerintahan Islam karena misinya semata merupakan petunjuk spiritual. Aktivitas Nabi tidak lebih daripada menyampaikan risalah yang bebas dari semua pengertian otoritas. Karena itu baginya "risalah bukan pemerintahan, agama bukan negara". ${ }^{77}$ Lebih jauh, Raziq menegaskan bahwa lembaga kekhalifahan secara keliru telah dilembagakan oleh para sahabat pasca wafatnya Nabi. Bukti dari keadaan ini adalah bahwa Nabi tidak pernah menunjuk pengganti sebelum wafatnya. Secara ideal tidak ada khalifah atau otoritas politik Islam apa pun dalam Islam. ${ }^{58}$ Sesungguhnya sangat masuk akal apabila dunia dapat menganut satu agama dan bahwa semua umat manusia dapat diatur ke dalam satu kesatuan agama. Namun, kepenganutan seluruh dunia pada satu pemerintahan dan dikelompokkan pada satu kesatuan politik dengan sendirinya bertentangan dengan sifat dasar manusia dan tidak berhubungan dengan kehendak Tuhan. Kebijakan Tuhan dalam tujuan yang bersifat duniawi adalah memelihara perbedaan-perbedaan di antara mereka. ${ }^{59}$

Pelencengan cita-cita reformis Islam yang dilakukan oleh murid-murid Afghani dan Abduh telah mendorong munculnya nasionalisme di Timur Tengah..$^{60}$ Akibatnya, gerakan nasionalisme yang awalnya berkembang di Mesir meluas hingga ke luar Mesir dan kemudian mempengaruhi suasana politik di Timur Tengah dengan panji-panji nasionalisme Arab. Bangkitnya nasionalisme

\footnotetext{
${ }^{56}$ Albert Hourani, Arabic Thought in Liberal Age, h. 214

${ }^{57}$ Charles Kurzman (ed.), Wacana Liberal: Pemikiran Islam Kontemporer tentang Isu-isu Gloal Oakarta: Paramadina, 2001), h. 11.

58Ibid., h. 3.

${ }^{59}$ Ibid., h. 17.

60John L. Esposito, (1992). The Islamic Threat: Myth or Reality? (New York: Oxford University Press, 1992), h. 61.
} 
Arab ini disebabkan pula oleh tumbuhnya kesadaran Arab sebagai akibat dari penindasan penguasa Turki pada akhir abad ke-19. Perkembangan despotisme Sultan Abdul Hamid pada akhir pemerintahannya telah membantu mempercepat orang-orang Arab terpanggil untuk memperbaharui Kerajaan Usmani. Tuntutan untuk melakukan pembaruan adalah berupa otonomi provinsiprovinsi Arab yang berada dalam lingkungan Kerajaan Usmani. Pada tahun 1908, ketika Sultan Abdul Hamid digulingkan, lembaga parlementer yang disebut Committe of Union and Progress (Komite Persatuan dan Kemajuan) dilembagakan untuk mengorganisasikan kerajaan.

Sangat disayangkan, tidak lama setelah komite ini dibentuk, terjadi konflik politik antara lembaga parlementer dengan kelompok-kelompok etnis yang ada dalam wilayah kerajaan. Konstituen etnik dalam wilayah kerajaan berharap bahwa pemerintah memberikan jaminan otonomi untuk menggantikan sistem sentralisasi. Komite, yang terdiri dari kalangan nasionalis Turki, menyadari bahwa hanya kelompok tertentu yang bisa menerima kebijakan mereka, yaitu orang-orang Turki. Karena itu, dengan bersandar pada nasionalisme Turki, mereka membuat kebijakan Turkifikasi untuk melaksanakan tujuan-tujuan mereka. ${ }^{61}$

Sejak saat itu khilafah Islam mulai tergerus dan akhirnya runtuh digantikan dengan Nasionalisme yang didasarkan atas persamaan bangsa ataupun bahasa. Hingga pada batas-batas ini Islam mengalami peminggiran, yang menjadi fluktuatif hingga saat ini. Namun yang jelas Islam tidak pernah lagi menjadi dasar persatuan bangsa-bangsa di Timur Tengah sebagai mana sistem khilafah sebelumnya. Melihat kenyataan ini maka sketasa Barat atas dunia Islam di Timur Tengah terbukti mewujud dalam perpecahan dunia Arab dan Timur Tengah dalam berbagai bangsa yang juga tidak sepi dari konflik.

\section{F. Desain Barat dalam Peta Politik Timur Tengah}

Ali Mohammed Naqvi sebagaimana telah disebutkan di atas pernah mengungkapkan bahwa nasionalisme merupakan produk impor yang dengan sengaja diekspor oleh para bangsa kolonial untuk mengacaukan persatuan di

\footnotetext{
61Zeine N. Zeine, The Emergence of Arab Nasionalism: With a Backgraound Study of Arab-Turkish Relation in the Near East(New York: Caravan Books, 1973), h. 75.
} 
dunia Islam. ${ }^{62}$ Persoalannya apakah benar hal itu yang terjadi? Menjawab pertanyaan ini realitas kebangsaan dan efek negatifnya menjadi penting untuk diungkapkan.

Sebuah bangsa pada dasarnya merupakan konstruksi historis dalam sejarah kemanusiaan, budaya dan ras sebuah bangsa, di mana eksklusivitas konsepsi ideologi yang diusung memiliki batasannya sendiri. Edward W. Said misalnya mengakui bahwa Nasionalisme memiliki keterbatasan dalam sistem pengetahuan dan politik, khususnya terkait dengan ideologisasi identitas kebangsaan, yang tidak hanya diagungkan dan menjadi "idol" namun juga menjadi ilusi. Dalam hal ini Edward menyamakan semangat nasionalisme dengan sentimen keagamaan ekstrim, yang walaupun tidak menjadi bagian utama, namun menjadi bagian yang terpenting pendorong lahirnya berbagai bentuk Fundamentalisme. ${ }^{63}$

Kebencian Said ini didasarkan tidak hanya karena eksklusivitas nasionalisme namun juga pada dampak negatif yang dapat muncul dari nasionalisme. Ia menyatakan bahwa nasionalisme telah memunculkan gerakan separatis dari kalangan minoritas yang termarjinalkan dan juga berdampak pada peminggiran peran agama. Sehingga seringkali agama dan nasionalisme dipertentangkan. ${ }^{64}$ Karena itu sebagian pihak melihat bahwa nasionalisme merupakan desain Barat untuk memecah belah bangsa Arab dan melemahkan Islam di Timur Tengah. Setidaknya nasionalisme merupakan bagian dari proses globalisasi dan modernisasi yang telah membawa dampak terhadap tatanan kehidupan dan sistem sosial budaya pada komunitas tertentu, tak terkecuali pada masayarakat di Timur Tengah. Memudarnya masyarakat tradisional di Timur Tengah juga merupakan bagian dari proses transformasi masyarakat terhadap nilai-nilai baru yang ditawarkan oleh globalisasi dan modernisasi. Seperti

\footnotetext{
${ }^{62}$ Ali Mohammed Naqvi, "Islam and Nationalism", dalam laman http://www.al-islam.org/ islamandnationalism/9.html. diunduh 15 Februari, 2008.

63Edward W. Said, "Sharpening the axe”, dalam Al-Ahram Weekly, Vol.26, 5 Juli 2001, h. 76.

${ }^{64}$ Said misalnya mempertanyakan bagaimana mungkin nilai-nilai universal kemanusiaan seperti kemerdekaan, demokrasi, Hak Azazi Manusia (HAM) ditegakkan dalam sistem kebangsaan yanng terbatas? Karenanya Said menyatakan Nasionalisme sebagai pagar pembatas moralitas kemanusiaan universal, tempat di mana tirani, kekerasan, dan penistaan terhadap nilai-nilai kemanusiaan justru terjadi. Li Yi, "Edward Said's Thoughts and Palestinian Nationalism", dalam Journal of Middle Eastern and Islamic Studies (in Asia), Vol. 5, No. 3, 2010: 105-120, h. 116.
} 
ditegaskan oleh Wilbert Moore, bahwa modernisasi adalah transformasi total masyarakat tradisional atau pra-modern ke tipe masyarakat teknologi dan organisasi sosial yang menyerupai dunia Barat yang ekonominya makmur dan situasi politiknya stabil?65

Karena itu pula Barat senantiasa melakukan intervensi ketika panArabisme menampakkan diri. Kasus ketika Saddam Husein sebagai representasi pan-Arabisme modern melakukan gerakannya, dimulai dengan memerangi Iran tahun 1980, yang dianggap sebagai basis peradaban Persia. Tujuannya adalah mencapai persatuan bangsa Arab yang telah tercacah dalam puluhan negara. Menurutnya "persatuan (bangsa Arab) tidak harus membebani, karena dapat dicapai melalui kesamaan opini persaudaraan. Persatuan mesti mendatangkan kekuatan kepada tiap individu yang berbeda, tanpa menghilangkan identitas nasional masing-masing".66 Dengan pandangan seperti ini, Saddam berupaya menginvasi daerah Arab, seperti Kuwait tahun 1990, yang diklaim sebagai bagian provinsi Iraq. Tindakan ini jelas mengindikasikan upaya panArabisme, walaupun Iraq sendiri tidak secara terbuka mengungkapkannya. Sebagian pihak melihat Saddam Husein sebagai reincarnasi dari Nasser. ${ }^{67} \mathrm{Hal}$ inilah yang memunculkan upaya USA terutama untuk mempersatukan negara Arab dan Israel memerangi Iraq.

Berdasarkan jabaran di atas dapat dikatakan bahwa peta politik di Timur Tengah didesain sedemikian rupa bagi kepentingan Barat. Upaya untuk menahan nasionalisme Arab jelas menunjukkan tindakan antisipatif untuk tidak membiarkan bangsa Arab bersatu, dan menguatkan adanya intervensi asing.

\section{G. Kesimpulan}

Konflik berkepanjangan antara Arab-Israel, dan maraknya gerakan fudamentalisme dan terorisme yang dilakukan baik oleh umat Islam dan nonIslam, menyebabkan beberapa pihak menyatakan bahwa nasionalisme

\footnotetext{
65Piotr Sztompka, Sosiologi Perubahan Sosial (Jakarta: Prenada, 2008), h. 152.

${ }^{66}$ Amatzia Baram, Culture, History and Ideology in the Formation of Ba'thist Iraq, 1968-89 (London: Macmillan, 1991), h. 121. h. 197.

67Martin Kramer, “Arab Nationalism: Mistaken Identity”, dalam Daedalus, Summer 1993: 171-206,
} 
merupakan produk impor yang dengan sengaja diekspor untuk mengacaukan persatuan di dunia Islam. Karena itu, kepada seluruh pihak yang cinta damai, mestinya dapat mengarahkan perhatian pada krisis identitas dan konflik berkepanjangan di Timur Tengah yang senantiasa bergejolak. Dalam hal ini peran dunia internasional sangat dibutuhkan untuk meminimalisir konflik, bukan justru memperkeruh konflik yang ada. Selanjutnya diharapkan kepada umat Islam khususnya agar dapat menyikapi perbedaan dengan mengembalikannya pada ajaran Islam sejati hingga seluruh perkataan dan perbuatan umat Islam benar-benar mencerminkan umat Islam yang rahmatan li al-alamin, bukan sebaliknya. Untuk itu keterbukaan dan visi global dalam melihat realitas lokal dan dunia menjadi kemestiaan dan tidak dapat ditawar. Umat Islam dalam hal ini harus mau belajar dari sejarahnya yang kaya kosmopolit dan universal. Semoga kedamaian menjadi cita-cita dan milik kita semua.[w] 


\section{BIBLIOGRAFI}

Ahmed, Shabir, Akar Nasionalisme di Dunia Islam, Bangil: Tim Al-Izzah, 2002.

Amir, Sulfikar, "Epistemologi Nasionalisme". http://serbasejarah.wordpress. com., diunduh 18 April, 2009.

Andrukaitis, Jason, "Egyptian and Israeli Nationalism: A View into the Relationship Between Nationalism and Violance", Junior Honors Seminar: Beyond Religious Fundamentalism. Rivier College, 2006.

Ayyad, Abdelaziz A., Arab Nationalism and the Palestinians 1850-1939. Jerusalem: Passia, Palestinian Academic Society for the Study of International Affair, 1999.

Baram, Amatzia, Culture, History and Ideology in the Formation of Ba'thist Iraq, 1968-89, London: Macmillan, 1991.

Betts, Richard K. (ed.), Conflict After the Cold War: Arguments on Causes of War and Peace, New York: MacMillan, 1994.

Brown, Alison, "The Renaissance", Terj. Saut Pasaribu, Sejarah Renaisans Eropa, Yogyakarta: Kreasi Wacana, 2009.

Cox, Harvey, Aspects of Political Development, Boston: Little Brown, 1965.

Dault, Adhyaksa, Islam dan Nasionalisme: Reposisi Wacana Universal dalam Konteks Nasional, Jakarta: Pustaka Al-Kautsar, 2005.

Delacroix, Eugene, "Nationalism". Stanford Encyclopedia of Philosophy, http://en.wikipedia.org/wiki/nationalism, diunduh 14 Januari 2014.

Dewi, Ita Mutiara, "Nasionalisme dan Kebangkitan dalam Teropong", dalam Mozaik. vol. 3, No. 3, Juli 2008.

Drysdale, A. \& G.H. Blake, "National Integrations: Problems, Processes and Prospects", The Middle East and North Africa: A Political Geography, New York: Oxford University Press, 1985.

Esposito, John L., The Islamic Threat: Myth or Reality?, New York: Oxford University Press, 1992.

Gauhar, Altaf, The Challenge of Islam, London: Islamic Council of Europe, 1978.

Gunawan, "Sistem Pemerintahan Masa Imperialisme Barat dan Pergerakan Nasional di Timur Tengah, http://gunawanktt.blog.uns.ac.id/2014/10/ 
07/ evolusi-sistem-pemerintahan-di-timur-tengah-bag-3/. Diunduh 3 Januari 2016.

Hitti, Philip K., History of The Arabs: From the Earliest Time to the Present, New York: Macmillan, 1970.

Hourani, Albert, Arabic Thought in Liberal Age: 1798-1939, Cambridge: Cambridge University Press, 1983.

Hudson, Michael C., "Cultural Pluralism in the Arab World". Arab Politics: The Search for Legitimacy, New Haven and London: Yale Univesity Press, 1977: 56-81.

Jones, Walter S., Logika Hubungan Internasional 2: Kekuasaan, Ekonomi Politik Internasional dan Tatanan Dunia, Jakarta: Gramedia Pustaka Utama, 1993.

Juergensmeyer, Mark, Terror in the Mind of God: The Global Rise of Religious Violence, Los Angeles: University of California, 2003.

Karppat, Kemal H. (ed.), Political and Social Thought in the Contemporary Middle East, New York: Praeger Publisher, 1982.

Kramer, Martin, "Arab Nationalism: Mistaken Identity", dalam Daedalus, Summer 1993: 171-206.

Kurzman, Charles (ed.), Wacana Liberal: Pemikiran Islam Kontemporer tentang Isu-isu Gloal, Jakarta: Paramadina, 2001.

Mestoko, Soemarsono, Indonesia dan Hubungan antar Bangsa, Jakarta: Pustaka Sinar Harapan, 1988.

Mulyana, Budi, Pemikiran Politik di Timur Tengah, https://hbmulyana. wordpress.com/2008/01/05/pemikiran-politik-di-timur-tengah, diunduh 5 Januari, 2008.

Naqvi, Ali Mohammed, "Islam and Nationalism", diunduh dari http://www.alislam.org/islamandnationalism/9.html, diunduh 15 Februari, 2008.

Rahman, Fazlur, Islam, New York: The Chicago Press, 1979.

Rahnema, Ali (ed.), Para Perintis Zaman Baru Islam, Bandung: Mizan, 1995.

Rouhana, Nadeem, Palestinian Citizen in an Ethnic Jewish State, New Haven: Yale University Press, 1997.

Rourke, J., International Politics in The World Stage, Beijing: Peking University Press, 2005.

Said, Edward W., "Sharpening the axe”, al-Ahram Weekly, Vol.26, 5 Juli 2001. 
Schmandt, Henry J., "A History of Political Philosophy", Ahmad Baidlowi dan Imam Baehaqi (terj.), Filsafat Politik: Kajian Historis dari Zaman Yunani Kuno sampai Zaman Modern, Yogyakarta: Pustaka Pelajar, 2009.

Stark, Rodney, One True God: Historical Consequences of Monotheis, Princeton: Princeton University Press, 2001.

Stoddard, Lothrop, Dunia Baru Islam (The New World of Islam), Jakarta: Panitia Penerbit, 1966.

Sztompka, Piotr, Sosiologi Perubahan Sosial, Jakarta: Prenada, 2008.

Yang, H. dan X. Ma, "The Orogin and Early Exprerience of the Pakistan Nationalism", dalam West Asia and Afrika, No. 2, 2002.

Yi, Li, "Edward Said's Thoughts and Palestinian Nationalism". dalam Journal of Middle Eastern and Islamic Studies (in Asia), Vol. 5, No. 3, 2010: 105-120.

Zaine, Zeine N., The Emergence of Arab Nasionalism: With a Backgraound Study of Arab-Turkish Relation in the Near East, New York: Caravan Books, 1973.

Zakzaky, Ibraheem Yaqoub El-, "Nationalisme", http://www. islamicmovement. org/nationalism.html\#introduction, diunduh 15 Februari 2008.

Zaman, Noor, et. al., "Islam and Nationalism: A Contemporary View". Interdisciplinary Journal of Contemporary Research in Business, Vol. 4, No. 5, September 2012.

Zhao, K., "From Arab Nationalism to Plastinian Nationalism: The Growth Process of the Palestinian Nation", dalam World Ethno-National Stidies, No. $1,2007$. 
